\title{
Manajemen Pengadaan Sarana Prasarana Sekolah
}

\author{
Tia Fajartriani, Wawan Karsiwan \\ STKIP Muhammadiyah Bogor, Indonesia \\ tia.fajar@gmail.com
}

\begin{abstract}
This research aims to evaluate the process of procurement of school infrastructure, whether so far the procedures used have been effective or not. This research is based on factual conditions where the process of infrastructure procurement in several schools is often inefficient and ineffective, without clear guidelines for the provision of infrastructure. The research method used is the research and development method used in developing the procedures for the procurement of facilities and infrastructure with the following stages: Preliminary Study, Development of Infrastructure Procurement Procedures, Validation of Procedure for Procurement of Facilities, Trials and Revisions, and Implementation of procedures. The research sample used as a source of data and information was the Principal, Deputy Principal of the School of Infrastructure, Head of School Facilities and Teacher Representatives. The data and information collected were assisted by using several research instruments, namely: Documentation Studies, Interview Guidelines, and Questionnaires. The results show that the probability (sig 2 tailed) is 0.003 and the table value on the two tailed test at the 95\% level is 11. It can be seen that the probability $<0.05$ (t table 11) is the bypothesis which states that there is a difference between Test 1 and Test 2. received. Meanwhile, the hypothesis which states that there is no difference between Test 1 and Test 2 is rejected.

Keywords: management; facilities; infrastructure
\end{abstract}

\begin{abstract}
ABSTRAK
Penelitian ini bertujuan untuk melakukan evaluasi terhadap proses pengadaan sarana prasarana sekolah, apakah selama ini prosedur yang digunakan sudah efektif atau belum. Penelitian ini, didasari oleh keadaan faktual dimana seringkali proses pengadaan sarana prasarana di beberapa sekolah tidak efisien dan efektif, tanpa adanya panduan pengadaan sarana prasarana yang jelas. Metode Penelitian yang digunakan adalah metode penelitian dan pengembangan yang digunakandalam melakukan pengembangan prosedur pengadaan sarana dan prasarana dengan tahapan: Studi Pendahuluan, Pengembangan Prosedur Pengadaan Sarana Prasarana, Validasi Prosedur Pengadaan Sarana Prasarana, Uji Coba dan Revisi, dan Implementasi prosedur. Sampel Penelitian yang digunakan sebagai sumber data dan informasi adalah Kepala Sekolah, Wakil Kepala Sekolah Bidang Sarana Prasarana, Kepala Sarana Prasarana Sekolah dan Perwakilan Guru. Data dan Informasi yang dikumpulkan dibantu dengan menggunakan beberapa instrument penelitian yaitu: Studi Dokumentasi, Pedoman Wawancara, dan Angket. Hasil Penelitian, terlihat probalitas (sig 2 tailed) adalah 0.003 dan Nilai Tabel pada two Tailed Test pada taraf 95\% adalah 11. Maka dapat terlihat bahwa, probabilitas $<0.05$ ( t table 11) hipotesis yang menyatakan terdapat perbedaan antara Uji 1 dengan Uji 2 diterima. Sementara, untuk hipotesis yang menyatakan tidak terdapat perbedaan anatara Uji 1 dan Uji 2 ditolak.
\end{abstract}

Kata Kunci: manajemen; sarana; prasarana

Submitted Feb 20, 2021 | Revised Mar 07, 2021 | Accepted Mar 10, 2021

\section{Pendahuluan}

Keberlangsungan pelayanan pendidikan tidak terlepas oleh ketersediaan sarana parasarana yang dimiliki oleh sekolah itu sendiri. Keberadaan sarana prasarana sebagai penunjang dalam pencapaian tujuan pembelajaran. Tanpa Sarana Prasarana yang memadai pencapaian tujuan pembelajaran tidak akan maksimal dapat dicapai. Dalam Undang-undang Republik Indonesia Nomor 20 Tahun 2003 tentang Sistem Pendidikan Nasional dinyatakan "Setiap satuan pendidikan formal dan non formal menyediakan sarana dan prasarana yang memenuhi yang memenuhi keperluan pendidikan sesuai dengan pertumbuhan dan perkembangan potensi fisik, kecerdasan intelektual, sosial, emosional, dan kewajiban peserta didik" ( Undang-Undang RI Tahun 2003 ).

Peraturan Pemerintah RI No 19 tahun 2005 tentang Standar Nasional Pendidikan Bab VII pasal 42 ayat 1 dan 2: (1) Setiap satuan pendidikan wajib memiliki sarana yang meliputi: perabot, peralatan 
pendidikan, buku dan sumber belajar lainnya, bahan habis pakai serta perlengkapan yang diperlukan untuk menunjang proses pembelajaran yang teratur dan berkelanjutan; dan (2) Dari setiap satuan pendidikan meliputi: lahan, ruang kelas, ruang pimpinan, ruang guru, ruang perpustakaan, ruang laboratorium, kantin, tempat berolah raga dan tempat beribadah, tempat bermain, tempat berekreasi, dan ruang tempat lain yang diperlukan untuk menunjang proses pembelajaran yang teratur dan berkelanjutan. (Paturan Pemeritah No. 19 RI Tahun 2005).

Dari dua ketentuan di atas, jelas bahwa keberdaan Sarana Prasarana di Sekolah merupakan bagian penting dalam mencapai tujuan pembelajaran. Oleh karenanya, Sekolah di tuntut untuk dapat menyediakannya, sehingga layanan pembelajaran dapat maksimal berjalan dengan baik. Terdapat beberapa keuntungan bagi sekolah yang memiliki kelengkapan sarana dan prasarana, antara lain: (1) kelengkapan sarana dan prasarana dapat menumbuhkan gairah dan motivasi guru dalam mengajar serta dapat mendorong siswa untuk belajar, sehingga pembelajaran akan menjadi efektif; (2) kelengkapan sarana dan prasarana dapat memberikan kemudahan dalam menentukan berbagai pilihan pada siswa untuk belajar, sehingga proses pembelajaran akan lebih bervariasi.(Tanjung, Annisa, \& Ridwan, 2016)

Dengan begitu pentingnya sarana prasarana sekolah bagi keberhasilan proses pendidikan, maka sekolah perlu menyediakan atau mengadakan sarana prasarana sekolah secara efisien dan efektif, sehingga mampu menjawab terhadap permasalahan pengelolaan sarana prasarana sekolah khususnya pengadaaan Sarana Prasarana sekolah. Dan Pengadaan Sarana Prasarana Sekolah, merupakan fungsi awal dalam manajemen sarana prasarana sekolah. Oleh karena itu, sekolah dalam melakukan pengadaan sarana prasarana sekolah perlu dipandu oleh pedoman pengadaan yang berlaku. Hal Ini sejalan dengan "The most fundamental problem in facilities management is lack of policy guidelines for infrastructural development in schools. In some schools, there are inadequate classrooms, staff offices, laboratories and workshops, libraries, study areas while in some, these facilities are adequately provided. This situation arises because the Federal, State and Local Governments have failed to establish policy directives on minimum standards in relation to school facilities" (Asiabaka, 2008)

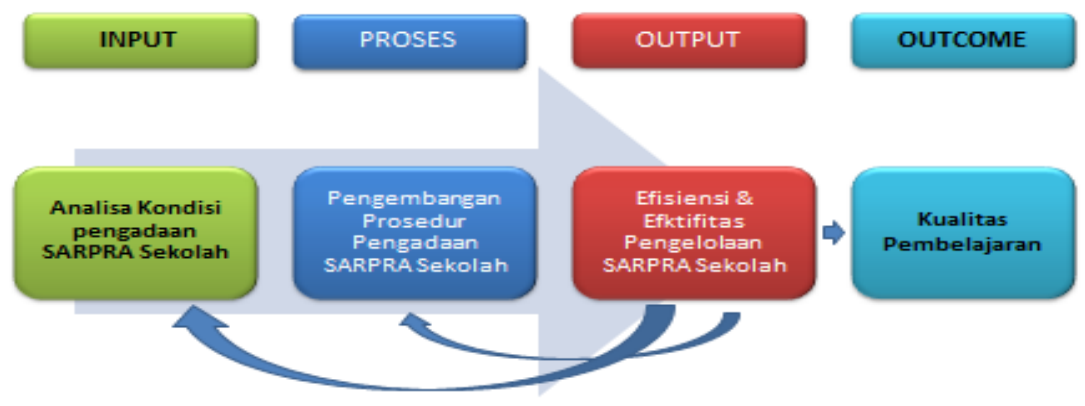

Gambar 1. Kerangka Penelitian

Beberapa Formulasi Permasalahan yang relevan untuk dikembangkan dalam penelitian ini dapat dirumuskan sebagai berikut: (1) Bagaimana Keadaan Sarana Prasarana Sekolah dalam Menunjang kegiatan Pembelajaran?, (2) Bagaimana Proses pengadaan Sarana Prasarana Sekolah yang dilakukan selama ini?, (3) Bagaimana Prosedur pengadaan Sarana Prasarana Di Kembangkan?, (4) Apakah terdapat Perbedaan Efisiensi dan Efektifitas dari Implementasi Prosedur Pengadaan Sarana Prasarana yang telah dikembangkan dengan kondisi sebelumnya?

Tujuan dalam penelitian ini yaitu, (1) untuk mengetahui keadaan sarana prasarana sekolah dalam menunjang kegiatan pembelajaran, (2) untuk mengetahui bagaimana proses pengadaan sarana prasarana sekolah yang dilakukan selama ini, (3) untuk mengembangkan prosedur pengadaan sarana prasarana yang akan digunakan di sekolah, (3) untuk Mengetahui Perbedaan Tingkat Efisiensi dan Efektifitas dari 
Implementasi Prosedur Pengadaan Sarana Prasarana yang telah dikembangkan dengan kondisi sebelumnya.

\section{Metode Penelitian}

Metode penelitian yang digunakan dalam penelitian ini adalah metode penelitian dan pengembangan. Tim Puslitjaknov (2008) bahwa pengertian penelitian pengembangan dalam bidang pendidikan (dalam penelitian pengembangan inovasi pembelajaran) adalah suatu metode penelitian yang memuat 3 komponen utama, yaitu: (1) Model Pengembangan, (2) Prosedur Pengembangan, dan (3) Uji coba Model atau Produk Pengembangan. (Silalahi, 2018). Sementara, Borg and Gall (1983) mengemukakan: "educational research and development, $\mathrm{R} \& \mathrm{D}$, is a process used to develop and validate educational products" (proses yang digunakan untuk mengembangkan dan memvalidasi produk-produk pendidikan).(Silalahi, 2018).

United Nations Conference On Trade And Development, menyatakan Penelitian dan Pengembangan (R\&D) terdiri dari empat jenis kegiatan, yaitu: Penelitian Dasar, Penelitian Terapan, Pengembangan Produk, dan Proses Pengembangan. Penelitian dasar karya eksperimental asli tanpa tujuan komersial tertentu. Penelitian terapan yang sering dilakukan oleh universitas adalah karya eksperimental asli dengan tujuan spesifik. Pengembangan produk adalah peningkatan dan perluasan produk yang ada. Proses Pengembangan adalah menciptakan proses baru atau yang ditingkatkan. (Nusa Putra, 2015). Penelitian dan Pengembangan menekankan produk yang berguna atau bermanfaat dalam berbagai bentuk sebagai perluasan, tambahan, dan inovasi dari bentuk-bentuk yang sudah ada.

Penelitian ini dilaksanakan dengan mengambil tempat penelitian di SMKS Giri Taruna 2 JL. Raya Parungsapi Km.4 Jasinga Kabupaten Bogor Provinsi Jawa Barat. Didirikan Pada Tahun 2009 dengan SK Pendirian No. 421/35-disdik Jawa Barat. SMKS Giri Taruna, menyelenggarakan pendidikan dengan Jurusan: Administrasi Perkantoran dan Teknik Kendaraan Ringan (Automotive) dengan jumlah rombel 15 Kelas. Yang menjadi Populasi dan Sampel dalam penelitian ini disesuaikan dengan kebutuhan dari Permasalahan dan Tujuan Penelitian, yaitu Terdiri dari, (1) Kepala Sekolah, (2) Kepala Bagian Sarana Prasarana Sekolah, (3) Guru-guru SMK yang berjumlah 30 Orang. Dalam Pengumpulan Informasi dan Data dalam peneletian digunakan beberapa instrument penelitian berupa: (1) Pedoman Wawancara; (2) Studi Dokumentasi, dan (3) Angket.

Analisis Data dilakukan dengan Uji Kuantitatif dengan menggunakan UJi T, dengan tujuan untuk menguji daya beda setelah dilakukan uji coba berupa implementasi SOP Yang telah dikembangkan dengan kondisi sebelumnya. Uji ini bertujuan untuk mengetahui persepsi responden atas kondisi sebelumnya dengan setelah uji coba SOP.

\section{Hasil dan Pembahasan}

Penelitian ini dilaksanakan dengan mengambil tempat penelitian di SMKS Giri Taruna 2 JL. Raya Parungsapi Km.4 Jasinga Kabupaten Bogor Provinsi Jawa Barat. Didirikan Pada Tahun 2009 dengan SK Pendirian No. 421/35-disdik Jawa Barat. SMKS Giri Taruna, menyelenggarakan pendidikan dengan Jurusan: Administrasi Perkantoran dan Teknik Kendaraan Ringan (Automotive) dengan jumlah rombel 15 dengan jumlah siswa

Dari hasil kajian lapangan beberapa hal yang menjadi temuan penelitian sesuai dengan fokus penelitian, Keadaan Sarana Prasarana Sekolah dalam Menunjang Kegiatan Pembelajaran.Secara Umum Keadaan Sarana Prasarana Sekolah yang menjadi Sampel Penelitian, masih dihadapkan pada berbagai keterbatasan. Akan Tetapi Sarana Prasarana Sekolah yang menjadi Penunjang utama Kegiatan Belajar Mengajar sudah cukup tersedia seperti Kelas, Laboratorium, Lapangan Olah Raga, Ruang Guru dan Ruang Kepala Sekolah.

Proses Pengadaan Sarana Prasarana Sekolah selama ini dilakukan secara sporadis, tidak sistematis dan tidak terprogram. Proses Pengadaan Sarana Prasarana dilakukan secara langsung apabila 
adanya kebutuhan langsung di sekolah dan diajukan secara lisan kepada kepala sekolah. Selanjutnya Pemenuhan Usulan Sarana Prasarana akan dilakukan apabila dana untuk kebutuhan tersebut tersedia.

Dari Hasil Temuan Di Lapangan Berkaitan Dengan Prosedur Pengadaan Sarana Prasarana Sekolah, dimana sekolah secara faktual belum memiliki Pedoman Berupa prosedur Pengadaan Sarana Prasarana Sekolah. Langkah Selanjutnya, dikembangkan prosedur Sarana Prasarana Sekolah Sesuai dengan Kebutuhan Sekolah. Dari hasil pengembangan Prosedur Pengadaan Sarana Prasaran Sekolah terdapat beberapa Instrumen yang menjadi kelengkapan Prosedur Saran Prasaran Sekolah Berupa: (1) Instruksi Kerja Perencanaan Kebutuhana Sarana Prasarana Sekolah, (2) Instruksi Kerja Pengadaan Sarana Prasarana Sekolah, (3) Instruksi Kerja Penataan Sarana Prasarana Sekolah, (4) Instruksi Kerja Pemeliharaan Sarana Prasarana Sekolah, (5) Instruksi Kerja Pengawasan Sarana Prasarana Sekolah, (6) Prosedur Manajemen Pengadaan Sarana Prasarana Sekolah, (7)Form (Formulir) Manajemen Pengadaan Sarana Prasarana Sekolah.

Sebagai Tahapan dalam Penelitian dan Pengembangan, keseluruhan prosedur tersebut diatas dilakukan validasi melalui Fokus Grup Diskusi dan Uji Coba sebanyak dua kali. Dan Setelah malaluai tahapan-tahapan tersebut, selanjutnya Keselruhan Prosedur Tersebut difinalisasi untuk dilakukan produksi.

Setelah melalui Uji Kelayakan Intrument, yang dari semula sebanyak 10 butir kemudian dikurangai menjadi 7 butir intem yang dilakukan proses analisis data lebih lanjut. Dan Dampak Implementasi prosedur Pengadaaan Sarana Prasarana Yang dikembangkan Dari Hasil Pengembangan Prosedur yang telah dilakukan, di dapat Persepsi Responden Atas Prosedur yang telah di Uji Cobakan dapat dilihat pada gambar 2 dan 3 .

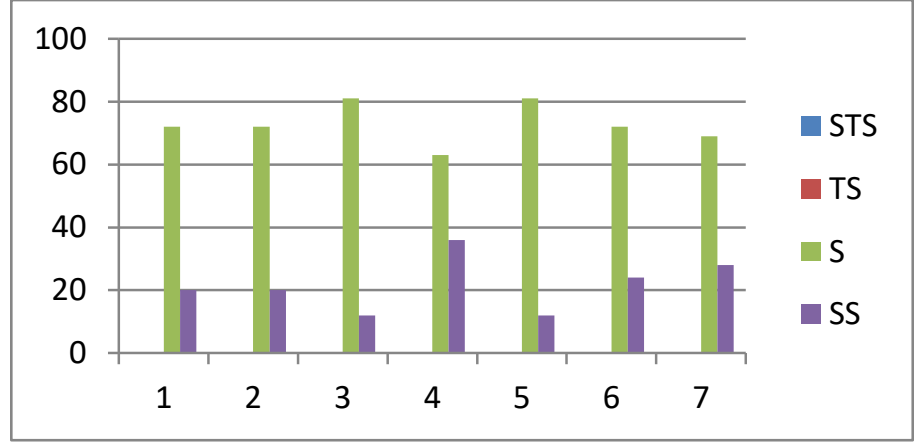

Gambar 2. Hasil Uji 1

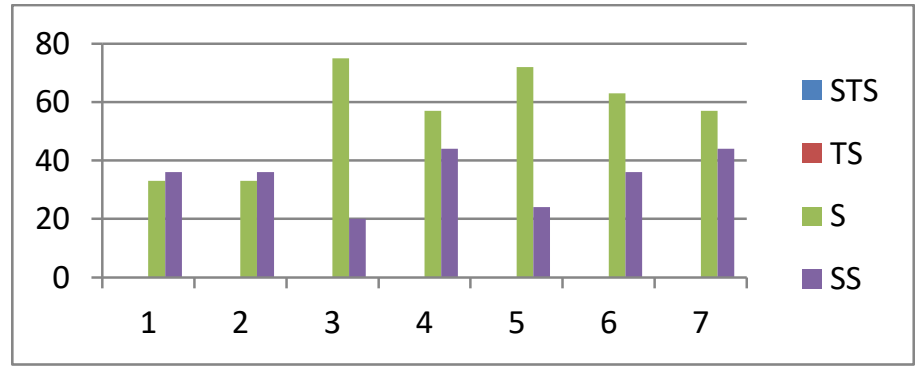

Gambar 3. Hasil Uji 2

Butir 1, Memudahkan dalam membuat perencanaan kebutuhan sarana prasarana;

Butir 2, Terdapat Kejelasan Informasi Dalam melakukan Pengadaan Sarana Prasarana;

Butir 4, Membantu dalam melakukan pekerjaan secara rutin dan berkala pengadaan sarana prasarana;

Butir 7, Adanya Kejelasan Deskripsi Tugas dan Tanggung Jawab setiap Bagian Dalam Pengadaan Sarana Prasarana Sekolah;

Butir 8, Dapat Memperhitungkan Duration of Time Pengadaan Sarana Prasarana Sekolah; 
Butir 9, Memberikan Kejelasan Spesifikasi Teknis Dalam pengadaan Sarana Prasarana;

Butir10, Memudahkan dalam melakukan evaluasi dan pelaporan pengadaan sarana prasarana.

Dari sebaran angket yang telah dilakukan, dapat dilihat bahwa dengan adanya prosedur pengadaan sarana prasarana sekolah sebagian besar responden menyatakan setuju dan dan sangat setuju, bahwa dengan adanya pedoman berupa Prosedur Pengadaan Sarana Prasarana Sekolah mendorong lebih efektif dalam pengelolaan sarana prasarana sekolah.

Dalam Undang-undang Republik Indonesia Nomor 20 Tahun 2003 tentang Sistem Pendidikan Nasional dinyatakan "Setiap satuan pendidikan formal dan non formal menyediakan sarana dan prasarana yang memenuhi yangmemenuhi keperluan pendidikan sesuai dengan pertumbuhan dan perkembangan potensi fisik, kecerdasan intelektual, sosial, emosional, dan kewajiban peserta didik" ( Undang-Undang RITahun 2003 ). Dari Undang-undang diatas, sangat jelas peran Sarana Prasarana Sekolah menjadi Kewajiban bagi Satuan pendidikan untuk menyediakannya. Proses Penyediaan Sarana Prasarana Sekolah terkait dengan Prosedur dalam pengadaan Sarana prasarana Sekolah.

Dalam Peraturan Pemerintah RI No 19 tahun 2005 tentang Standar Nasional Pendidikan Bab VII pasal42 ayat 1 dan 2: (1) Setiap satuan pendidikan wajib memiliki sarana yang meliputi: perabot, peralatan pendidikan, buku dan sumber belajar lainnya, bahan habis pakai serta perlengkapan yangdiperlukan untuk menunjang proses pembelajaran yang teratur dan berkelanjutan; dan (2) Dari setiap satuan pendidikan meliputi: lahan, ruang kelas, ruang pimpinan, ruang guru,ruang perpustakaan, ruang laboratorium, kantin, tempat berolah raga dan tempat beribadah, tempat bermain, tempat berekreasi, dan ruang tempat lain yang diperlukan untuk menunjang proses pembelajaran yang teratur dan berkelanjutan. (Paturan Pemeritah No. 19 RI Tahun 2005).

Dari Pentingnya sarana prasarana sebagai penunjang kegiatan belajar mengajar, maka proses manajemen sarana prasarana merupakan upaya yang penting dilakukan oleh satuan pendidikan. Manajemen Sarana Prasarana dapat diartikan sebagai segenap proses pengadaan dan pendaya gunaan komponen-komponen yang secara langsung maupun tidak langsung menunjang proses pendidikan untuk mencapai tujuan pendidikan yang efektif dan efisien (Barmawi dalam Khoiriyah, Sudjarwo, \& Rini, 2014). Facilities management is a process that ensures that buildings and other technical systems support the operations of an organization (Asiabaka, 2008).

Sarana Prasarana Pendidikan pada dasarnya dapat dibagi empat kelompok, yaitu: tanah, bangunan, perlengkapan dan perabotan sekolah. Dan Ruang lingkup Manajemen Sarana Prasarana Meliputi: 1) perencanaan kebutuhan, 2) pengadaan, 3) penginventarisasian;4) penggunaan, 5) pemeliharaan, 6) penghapusan, dan 7) pengembangan.(Rohiyat, 2008). Perencanaan sarana dan prasarana adalah suatu proses memikirkan dan menetapkan program pengadaan fasilitas sekolah, baik yang berbentuk sarana maupun prasarana pendidikan dimasa yang akan datang untuk mencapai tujuan tertentu (Bafadal, 2008).

Selanjutnya, Standard Operational Procedure (SOP) adalah pedoman yang berisi prosedurprosedur operasional standar yang ada di dalam suatu organisasi yang digunakan untuk memastikan bahwa setiap keputusan, langkah atau tindakan dan penggunaan fasilitas pemrosesan yang dilaksanakan oleh orangorang di dalam suatu organisasi, telah berjalan secara efektif. (Hadiwoyono \& Panjaitan Dalam Kadafi \& Amirudin, 2017), konsisten, standar, dan sistematis. Menjelaskan bahwa Standar Operasional Prosedur (SOP) harus dibuat secara komprehensif untuk mempermudah dalam mendapatkan bukti sehingga dapat membantu proses penyelesaian suatu masalah. (Yen, et.al dalam Kadafi \& Amirudin, 2017). SMKS Giri Taruna dalam pengelolaan sarana prasarana sekolah selama ini dilakukan tanpa dipandu dengan pedoman pengelolaan sarana prasarana sekolah. Proses Pengadaan Sarana Prasarana sekolah selama ini dilakukan secara langsung ketika ada kebutuhan sarana prasarana. Dengan Standar Operasional Prosedur yang telah dikembangkan dan diujicobakan di dapat persepsi responden secara umum positif terhadap adanya prosedur yang dikembangkan. 
Dari hasil Uji Coba Prosedur dilakukan analisis uji beda dengan menggunakan uji t dengan hasil dapat dilihat pada tabel 1 dan 2.

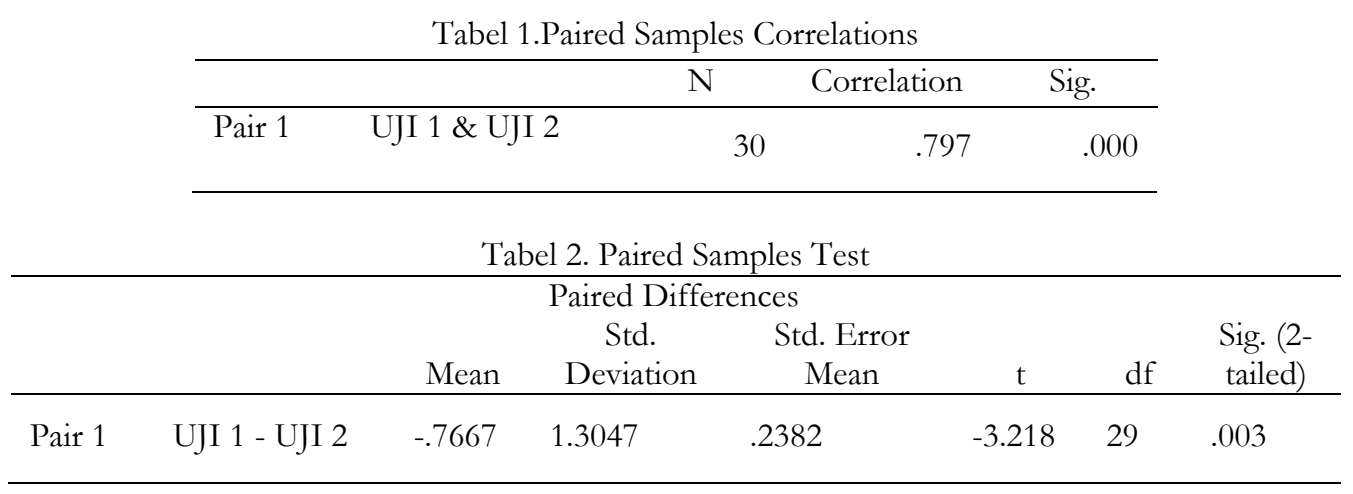

Dari Tabel di atas, terlihat probalitas (sig 2 tailed) adalah 0.003 dan Nilai Tabel pada two Tailed Test pada taraf 95\% adalah 11. Maka dapat terlihat bahwa, probabilitas $<0.05$ ( $\mathrm{t}$ table 11 ) hipotesis yang menyatakan terdapat perbedaan antara Uji 1 dengan Uji 2 diterima. Sementara, untuk hipotesis yang menyatakan tidak terdapat perbedaan anatara Uji 1 dan Uji 2 ditolak.

\section{Kesimpulan}

Kesimpulan penelitian ini, adalah (1) sarana prasarana sekolah perlu dikelola dengan baik, hal ini dikarenakan sarana prasarana secara langsung mendukung terhadap kualitas pelaksanaan kegiatan belajar mengajar, (2) Salah satu aspek penting yang harus dimiliki dalam tata kelola sarana prasarana sekolah adalah ketersediaan panduan manajemen kebijakan pengadaan sarana sekolah, dimana didalamnya berupa prosedur yang harus dilakukan dalam proses pengadaan sarana prasarana sekolah, (3) Dengan prosedur yang dimiliki diharapkan dapat berdampak terhadap keteraturan dan kepastian dalam proses pengadaan sarana prasarana sekolah.

Adapun rekomendasi peneliti untuk sekolah yang menjadi objek penelitian, yaitu : (1) Pengelolaan Sarana Prasarana sekolah perlu dilakukan secara efektif dan efisien, dikarenakan dengan ketersediaan sarana prasarana dapat menunjang terhadap pencapaian tujuan pembelajaran; (2) Ketersedian Panduan atau Pedoman Kebijakan Manajemen Pengadaan Sarana sekolah menjadi keharusan untuk Satuan Pendidikan, dengan panduan yang ada memberikan kepastian tata kelola sarana sekolah; (3) Pada Tahap awal Panduan Kebijakan Manajemen Pengadaan sarana sekolah dapat disusun sederhana dengan mempertimbangkan kondisi dan kebutuhan sekolah.

\section{Daftar Pustaka}

Asiabaka, I. P. (2008). Facilities Management In Schools. New York Science Joumal, 10-21.

Bandono, \& Ardhi, W. (2015). Pengelolaan Sarana dan Prasarana di Sekolah Dasar Negeri 01 Tohu dan, Karanganyar. Profesi Pendidikan Dasar, 2(1), 41-48.

Creswell, J. W. (2009). Research design: Qualitative, quantitative, and mixed methods approaches. Research Design qualitative quantitative and mixed methods approaches (Vol.3rd). https://doi.org/10.1016/j.math.2010.09.003

Duyar, I. (2010). Relationship between school facility conditions and the delivery of instruction: Evidence from a national survey of school principals. Journal of Facilities Management, 8(1), 8-25.

Kadafi, M., \& Amirudin. (2017). Penyusunan Standar Operasional Prosedur (SOP) Program Studi di Politeknik Negeri Samarinda yang Mengacu pada Penilaian Standar Akreditasi Badan Akreditasi Nasional Perguruan Tinggi ( BAN-PT ) Menggunakan Program Mind Manager dan Microsoft Visio Preparat. SNIT Politeknik Negeri Balikpapan. 
Khoiriyah, S., Sudjarwo, S., \& Rini, R. (2016). Manajemen Sarana Prasarana Pendidikan Sdn 1 Pendowo Asri Dente Teladas Tulang Bawang. Jurnal Manajemen Mutu Pendidikan, 4(3).

Lepkova, N., \& Uselis, R. (2013). Development of a quality criteria system for facilities management services in Lithuania. Procedia Engineering, 57, 697-706.

Nusa Putra, (2015), Research \& Developmet Penelitian dan Pengembangan: Suatu Pengantar, Jakarta, PT. Raja Grafindo Persada

Silalahi, A. (2018). Development research \& research and development, (July). https://doi.org/10.13140/RG.2.2.13429.88803/1

Sugiyono, (2016). Metode Penelitian Kombinasi (Mixed Methods), Bandung, Alfabeta

Tanjung, F. Z., Annisa, M., \& Ridwan. (2016). Analisis Sarana Dan Prasarana Sekolah Dasar. Jurnal Pendidkan Indonesia, 5(2), 840-853. 